\title{
National Research Assessment Frameworks, Publication Output Targets and Research Practices: The Compliance-Habitus Effect
}

\author{
Julie Rowlands \\ Senior Lecturer, School of Education, Deakin University, Australia - \\ Corresponding author \\ julie.rowlands@deakin.edu.au \\ Trevor Gale \\ Professor, School of Education, University of Glasgow, UK
}

\begin{abstract}
In this paper we consider relationships between national research assessment and publication output targets within academic workload models, theorising their potential impact on research practices and the academic habitus. Thinking with Bourdieu's theory of practice, we draw on examples from higher education systems within the United Kingdom and Australia to argue that what an agent has done in the past plays a potentially significant role in the reformation of their own habitus. In relation to academics complying with publication output targets, whatever form those targets may take, we posit that this has implications for what research is done, how, by whom and where, and also for how researchers are disposed, or not, towards what research is perceived to be possible or desirable.
\end{abstract}

\section{Keywords}

Bourdieu - habitus - output targets - academic workload - research assessment 
Against a backdrop of struggle for the place of universities in the reordering of society, in this paper we examine relations between research assessment frameworks and publication output targets and their potential impact on research practices and the academic habitus. By targets we mean either a numerical target or a qualitative standard to be achieved, or some combination of the two.

Many nations have adopted research assessment models as a way of ranking the research performance of individual universities, often in connection with some allocation of performance-based research funding (see e.g. Wright et al., 2014; Schulze-Cleven and Olson, 2017; Johnston and Reeves, 2018). In some nations, performance-based academic workload models are also common for individual academics whose workloads comprise some combination of teaching, research and administration or service (Vardi, 2009; Papadopoulos, 2017). Within some of these academic workload models, such as in certain universities in Australia, the proportion of an academic's official workload allocated to research is determined by their research output in a defined number of preceding years (Kwok, 2013; Kenny, 2017). Viewed as a mode of governance, research assessment frameworks and performance-based academic workload models provide mechanisms for shaping the direction of academic work and targeting the products of that work to particular ends. They do this by forming part of strengthened internal processes associated with research management: an institutional response to policy pressures for productivity gains guided by new public management and comparisons between the performance of universities (Glaser, 2016).

Publication output targets, in their myriad forms, can be central components of academic workload models, which link the productivity of individual academics to aspirational institutional targets for research output associated with different levels of academic appointment. We argue these targets tend to be informed, either directly or indirectly, by research assessment exercises such as the Research Excellence Framework (REF) in the United Kingdom (UK) and the Excellence in Research for Australia (ERA). However, the connection between research assessment exercises and publication output targets applied to individual academics is also the subject of considerable academic

1 The authors gratefully acknowledge Dr Shaun Rawolle and Dr Stephen Parker for this helpful comments and suggestions in relation to a prior version of this paper, the contribution of the Warrnambool Collective of researchers at Deakin University and elsewhere, and anonymous reviewers. 
debate (see for example McNay, 2015). It is this debate that sparked our interest in the relationship between national research assessment and institutional governance mechanisms to manage and monitor the research output of individual academics. In particular, we are interested in the potential impact of publication output targets, in whatever form they may take, on the research practices of academics. Research practices include not only academic writing and publishing but also decision-making about what research to undertake, when, where, with whom and how, the development of research proposals, collaboration and mentoring, fieldwork, laboratory work, instrument design, data analysis, journal editing, peer review and dissemination of findings in blogs and reports. While our focus in this paper is on publication output targets, we also note that institutional performance-based research management mechanisms may contain measures related to research income and supervision of PhD completions, among other matters.

In spite of the widespread acceptance of publication output targets as a central mechanism for aligning academic outputs to university goals and increasing academic productivity, surprisingly little research has considered the way research practices may be changed through such mechanisms or the broader implications of these changes for the structure and function of academic research. This is despite the burgeoning literature on research evaluation and assessment. Instead, prior scholarship has tended to focus on the effects of research evaluation on research outputs such as publications (Marques et al., 2017), on academic identity (Waitere et al., 2011), on higher education institutions and individuals (Lucas, 2006) and on individual disciplines (Wright, 2014). However, Shore and Wright among others point to "perverse effects" when individuals are "incentivized to compete and perform according to the new norms of accounting" (2015, p. 422). While in some fields there is emerging debate about the usefulness of modelling the effects of targets on practice for example, on the power of indicators attached to global targets (FukudaParr et al., 2014) - more specific research in higher education is required to theorise the specific connections between pressures to comply with publication output targets, the research practices of individual academics and their (academic) habitus.

In undertaking this work we draw on Pierre Bourdieu's theory of practice, where practice is understood as the product of internalised knowledge - expressed as inclinations, tendencies and propensities - and which enable agents to make sense of not only what is taking place but what might take place, so as to realise a particular aim or objective (Bourdieu, 1977). In this way Bourdieu describes practice as being generated and informed by the habitus (Bourdieu and Wacquant, 1992), where habitus is a stable but not 
unchanging system of dispositions or schemes that operate as pre-thought or intuition but which lead to thoughts and actions within specific fields (Bourdieu, 1977).

This practice-based approach provides a useful way of theorising the complex inter-relationships between national research assessment, compliance pressures associated with academic workload management and the research practices of academics. It also provides a means of responding to prior critique that despite increasing scholarship on the effects of research assessment and research management, "studies of actual changes in research practice are rare" (Hammarfelt and de Rijcke, 2015, p. 63), tending instead to have focused on numerical indicators of research outputs and self-reported changes in academic identity (Glaser, 2016). Moreover, while some have written about the relationship between research assessment and/or institutional performance based research management and research practice (see for example Blackmore, 2010), other studies do not appear to have considered the relationship between these governance mechanisms and academic research practice in the context of practice theory.

Bourdieu's theory of practice is apposite for this analysis because of the extensive empirical work he conducted within higher education and his theorisation of the ways in which power, and therefore valued resources or capitals, are differentially produced and deployed within and between universities (see Bourdieu, 1988; Bourdieu, 1996). In this context, research assessment frameworks are regimes of governance that contribute to the structuring of higher education and disciplinary fields and which impact not only on the research practices of individual and teams of academics but also on their multiple unthought dispositions towards what research is considered desirable or achievable, or not, and whether, how and why it might be undertaken.

In expanding on these issues, we begin below with a short account of Bourdieu's theory of practice, the association between habitus and practice, and the place that pedagogic work plays in the formation and reformation of the habitus within fields. We then discuss the role of national research assessment in shaping academic workload models and how, in some nation states and universities, these can go so far as to determine the proportion of time allocated to research practice. Two vignettes are provided as ways of drawing out these issues, although we hasten to add that our approach is illustrative of how we conceive of research practice and does not provide an account of specific institutions or agents. We build on thinking about the mutually constituted nature of practice and habitus by considering the effect of pressures to comply with publication output targets on research practice and the role this might potentially play in re/forming the academic habitus, in particular 
in response to an agent's own practices. We conclude by making a case for the use of Bourdieu's theory of practice in future empirical studies that consider the effects of research assessment frameworks and/or publication output targets on the actual research practices of academics, and on their dispositions toward research. We argue that the implications of what we have coined the compliance-habitus effect, are especially important at this historical moment. Understanding changes in current research practice enable us to contribute to a conversation initiated by May (2005) about the transformation of academic production.

\section{A Brief Account of Bourdieu's Theory of Practice}

We commence our theorisation of changes in research practice from the position that for Bourdieu, practice is interconnected with capital and field through habitus (Reay, 2004b). As Bourdieu outlines these relations, fields (e.g. higher education) are bounded, contested and hierarchical social spaces (Grenfell, 2010) within which agents (e.g. researchers) are "defined by their relative positions" according to the measure and value of the capital or valued resources they possess (Bourdieu, 1985, p. 724). The boundaries of a field are defined by the extent to which its dominant capital (e.g. scientific knowledge) has purchase. Capital comes in various elemental (social, economic, cultural, symbolic) or compounded forms (journalistic, political, juridical) with a value specific to the field or fields within which it is held (Bourdieu, 1986). Different forms of capital are produced and accumulate within different fields arising from the specific practices that take place there; for example, academic, scientific and intellectual capital or power accumulate in response to managerial, scholarly, scientific and research practices (Bourdieu, 1988; Rowlands, 2017b). In play as oppositional forces, Bourdieu named academic capital as being generated through holding a senior position within the organisational hierarchy of a university and exercising the financial and hierarchical power that this position inherently brings. In contemporary terms, academic power equates to holding a managerial role and thus to managerial practices. In contrast, intellectual capital reflects reputational power produced through scholarly and scientific (including the social sciences) research practices (Bourdieu, 1988; Rowlands, 2017b). Fields are intersecting social spaces that operate as sites of struggle over which species of capital is dominant and in relation to efforts by agents to increase their share of the dominant capital, such as is the case in relation to the often fierce competition between academic and intellectual capital (Rowlands, 2013). Bourdieu named the university field (Bourdieu, 1988) 
as encompassing universities that are also competing organisational entities. Others have described broader fields of higher education, encompassing not only networks of universities but also additional higher education providers (see Marginson, 2008). As with other fields (Lingard and Rawolle, 2011), university and higher education fields are scalar, intersecting at local, national and global levels (Buchholz, 2016). In contrast to academic capital and managerial practice, which are entirely generated within the university field, only some intellectual capital and scientific capital is produced there as much intellectual capital is produced specific disciplinary fields (Bourdieu 1988).

Warde describes three distinct but connected ways in which Bourdieu refers to the notion of practice (2004: $\left.5^{-6}\right)$. First, practice is differentiated from theory (see for example Wacquant, 1989), represented by a juxtaposition between what Bourdieu defined as scientific or academic knowledge and the real-world knowledge derived "in the moment" of everyday life (Bourdieu and Wacquant, 1992: 70). Second, Bourdieu referred to practice as a "coordinated, recognisable and institutionally supported practice" (Warde, 2004: 6), such as an officially recognised sporting activity (Bourdieu, 1984: 218), a doctor's practice or a research council. Third, practice refers to purposeful and meaningful activity or action such as giving a gift (Bourdieu, 1990) or doing scientific research (Bourdieu and Wacquant, 1992).

Practice is the result of knowledge that arises from history but which reveals itself in the present as skills, proficiencies and competencies, enabling the agent to grasp not only what is occurring but also what might yet occur in the future so as to realise a specific objective or goal (Rowlands and Gale, 2017; Webb, 2012). In explaining this, Bourdieu often compared practice to playing a game (Bourdieu, 1990; Bourdieu, 1998). It is the habitus that makes possible this manifestation of practice as game through what Bourdieu describes as being "in the present in relation to a coming moment" (Bourdieu, 1998: 82). The habitus is generated by the social world and functions as a "durable and transposable but not immutable" system of dispositions through which agents see, understand and experience that world (Grenfell, 2012, p. 52).

This generation of the habitus is known as pedagogic work (Bourdieu and Passeron, 1977). It is first a product of a diffuse initiation into the culture of a social formation or group to which the agent belongs as a child, through a process of primary pedagogic work, which takes place within the family or surrogates and immediate community (Wacquant, 2011, p. 86). However, the habitus is not fixed, being subject to subsequent formation and reformation (Gale and Mills, 2013).

A characteristic of the habitus is that it can be both individual and collective (Bourdieu and Wacquant, 1992). This means dispositions comprising the 
habitus and held individually (albeit still the social inscribed on the individual) can also be shared by a group arising from a common or comparable shared history (Bourdieu, 1990) or positioning within a common field (Wacquant, 2016). Bourdieu and Wacquant describe a collective academic habitus (1992) as encompassing dispositions towards the academic game. It is the academic habitus that enables mastery (or not) of the rules (both tacit and explicit) that contribute to structuring of the given university or disciplinary field (Reay, 2004a) depending at least partly on relative holdings of intellectual capital (Rowlands, 2013).

The habitus generates practice within fields and it is also the habitus that enables the transfer of certain practices from one field to another (Bourdieu, 1984, p. 73; Rawolle, 2010).

It is this complex and multidirectional relationship between habitus and practice within and between fields that sets the theoretical context for what follows: a brief analysis of the practice of research assessment at various levels within the subfield of higher education. We begin with a discussion of national research assessment schemes before considering the relationship between these schemes and publication output targets within academic workload models.

\section{Metrics-based Research Assessment Exercises and Publication Output Targets within Academic Workload Models}

The world's first national research assessment exercise commenced in the UK in the 1980s (Lewis, 2014; McNay, 2016) and since then many post-industrial nations (although notably not the USA) have implemented schemes to both assess and rank the performance of university research, drawing heavily from each other in the process (Wright et al., 2014, p. 2; OECD, 2014). Such schemes are partly a response to neoliberal thinking which aims to govern the provision of services by introducing quasi markets (Marques et al., 2017). They reflect the implementation of private sector management techniques such as audit and accountability within public sector organisations (Strathern, 2000). Research assessment exercises also reflect global, regional and national policy discourses around the importance of innovation for driving economic growth, the role of universities in the production of innovation through excellent research, however defined (WEF, 2018), and a desire to provide a performance incentive at the same time as containing the cost of research (Wright, 2014).

However, research assessment schemes are also highly contentious (Lewis, 2014). There are debates about what is measured and how (Wright et al., 
2014), and criticisms of the effects of these schemes on the form and nature of research and on resultant research concentrations within elite institutions (Krucken, 2014). There are further criticisms of potential effects on the research behaviours, outputs and careers of individual academics (Lewis, 2014; Sato and Endo, 2014). It is also argued, particularly by researchers in the humanities and the social sciences, that research assessment processes favour the hard sciences, male researchers and those from Anglophone backgrounds (Wright et al., 2014). Although not part of all research assessment schemes, the most strident criticism is reserved for the use of bibliometrics within some systems (sometimes abbreviated to metrics) as a proxy for the quality of research output (Wilsdon et al., 2015). ${ }^{2}$

In the following we provide a brief summary of the research assessment frameworks currently in place in the UK and Australia as two contrasting examples. While the UK and Australia operate higher education systems that are very similar, their systems of research assessment represent two contrasting positions in the global higher education field. As a result, they are potentially of wider importance for understanding research practice and academic work more generally.

Within the UK, the performance-based Research Excellence Framework $(\mathrm{REF})$ determines the proportion of quality-related research $(\mathrm{QR})$ funding distributed to individual universities (HEFCE, 2017a). The first round of research assessment under the REF was undertaken in 2014 (REF, 2014). This current scheme replaced the former Research Assessment Exercise - the RAE (HEFCE, $2017 \mathrm{~b}$ ). The second round of research assessment under the REF will be undertaken in 2021 and will assess three elements of research: outputs $(60 \%)$, impact $(25 \%)$ and environment ( $15 \%)$, with determinations about the quality of research at individual institutions being made on the basis of the volume of research activity assessed as world-leading and internationally excellent (REF, 2018b). As with RAE 2008, REF 2014 used disciplinary sub-panels to review research by units of assessment (e.g. Education), considering the "'four best" publications of each academic submitted for assessment", while panels also used bibliometrics where appropriate (although few actually did) (Wright et al., 2014, p. 34). REF 2021 will consider a minimum of one and a maximum of five outputs attributed to every academic with significant responsibility for research, with an average of 2.5 outputs per researcher (REF, 2018a). The significant change here is an increase in the number of academics whose research is submitted for assessment: that is, previously institutions could choose which

2 As one response to this, see the San Francisco Declaration on Research Assessment (American Society for Cell Biology, 2012). 
researchers to include and which to exclude. In REF 2021, all researchers must be included.

Assessment of research impact was introduced across the UK for the first time in the REF 2014 exercise (Watermeyer, 2016). This involved universities submitting impact case studies for evaluation by expert sub-panels (Khazragui and Hudson, 2015: 56), which considered the extent to which the research had a "demonstrable societal outcome - and thus an evident public benefit" (Wright et al., 2014: 35, emphasis original). That is, the assessment of impact represented an attempt to move away from narrow definitions of excellence (Wright et al., 2014) and towards demonstrable changes to policy and/or practice that have resulted from research.

Within Australia, the performance based Excellence in Research for Australia program (ERA) evaluates fields of research (discipline groups) either by metrics alone or, in disciplines where the metrics may not be sufficiently robust, by peer review informed by metrics (Hicks, 2012: 255; ARC, 2017). There are currently three broad categories of indicators: research quality (citation analysis and/or peer review and other ERA indicators); research activity (volume of research income and publication outputs); and research application (commercialisation) (ARC, 2017). Parallel to ERA, a formal assessment of research engagement and impact was being undertaken for the first time in 2018. Impact is defined as the contribution research makes to "economic, social, cultural and other benefits" while research engagement involves "collaboration between universities, industries and other end-users of research" (ARC, 2018). Each is assessed separately by field of research: engagement by metric indicators and narrative statements; and impact by qualitative studies supplemented by metrics if available (ARC, 2018). Although in prior years outcomes of ERA evaluations contributed to determinations about research block grant distribution to Australian universities (Hicks, 2012), changes in 2017 removed the connection between grant allocations to individual universities and outcomes of the ERA process. ERA is therefore now a compulsory institutional and disciplinary benchmarking and ranking exercise with no direct funding implications.

Historically, Australia has tended to favour a quantitative measurement of research output via performance indicators, largely to contain costs (Lucas, 2006). Academic debates within Australia about the impact of such indicators on research outputs therefore predate the introduction of the ERA or its predecessor, the Research Quality Framework - the RQF (Kwok, 2013). For example, Australia's share of journal publications increased dramatically in all fields between 1989 and 2000 (Butler, 2003). However, it is argued that while the quantity of journal articles published had increased, the quality-measured by the 
impact factor of the journals in which these papers were published—had not (Hicks, 2009). Thus, quantity had increased at the expense of quality. Since then the situation has become more complex (Butler, 2010) at least partly because the ERA process currently favours both quantity and proxy measures of quality - that is, numbers of journal articles published in top-ranked international journals. However, in this scenario, quality proxies act as a hurdle requirement after which quantity is the measure used. That is, the quantity of outputs (albeit produced at threshold quality standards) remains a significant driver of research practice.

Research findings on the impact of research assessment on the publishing practices of UK researchers appear much more mixed than for Australia. For example, it is argued that there was a shift in emphasis from quantity to quality from the mid-199os and that there is currently no "incentive to publish more" (McNay, 2015, p. 67), although some analyses of changing patterns of academic publication in the UK report shifts towards journal articles over monographs and book chapters (Adams and Gurney, 2014; Marques et al., 2017). This claimed shift is not entirely borne out across disciplines and there remain rewards for researchers and institutions in the double weighting that the REF allows to be attributed to monographs, which tends to favour particular disciplines (e.g. History and the Humanities and Arts more broadly). Nor is the shift driven by the practices of sub-panels, which seem determined to assess the quality of outputs irrespective of where they are published. However, Butler argues that performance based research funding has encouraged UK academics to publish more in comparison to the past, although this may have varied over time (2010; see also Oancea, 2014).

The new arrangements for REF 2021 have the potential to engender a mixed economy in terms of publication quantity, albeit within limits. That is, some researchers are being encouraged to focus their energies on and access support for publishing just one high quality article, to meet the minimum standard, while others who are adept at publishing high quality articles are being encouraged to publish more - up to five. Whether one output or five, the number of articles required to be submitted by a unit of assessment is finite, a function of the number of eligible researchers in the unit. It is the flip side of the Australian context: in the UK, quantity acts as a hurdle requirement after which quality is the measure used to determine levels of funding received and it is the quality of outputs, defined in terms of originality, significance and rigour, that is the primary driver of research practice.

Research excellence is the primary determinant of the relative status and standing of universities and their departments or schools within the global higher education field (Marginson, 2006). In this light, the connection 
between institutional targets for research output that derive from national research assessment exercises and goals set for individual academics within academic workload models can be quite explicit. In what follows we introduce academic workload allocation models and their potential to place pressure on academics to produce (quantitatively and qualitatively) measurable research output, highlighting illustrative examples from the UK and Australia.

\section{$4 \quad$ Academic Workload Allocation Models}

Burgess, Lewis and Mobbs define an academic workload allocation model as:

...a human activity system at the level of the HE department that carries out aggregate planning to reconcile requirements and capacity in line with strategic goals and in particular promotes equitable workload allocation to individuals (Burgess et al., 2003, p. 219).

In general, such models require standardised formula for allocating workload to teaching, research and administration or service activities for individual academics, frequently on an hours or other time basis (De Angelis and Harvie, 2009). ${ }^{3}$ While the organisation and allocation of academic labour in some form or other is not new, the development of documented and sometimes complex procedures and proformas for this purpose is more recent and becoming widespread, including within the UK, Australia and across Europe (Burrows, 2012; Teichler et al., 2013). However, there is comparatively little empirical research on their impact (Kenny and Fluck, 2014). One study of a range of models in place within an Australian university suggests that academic staff dissatisfaction with these models increases proportionate to their complexity or specificity (Vardi, 2009), while a British study found a range of issues associated with workload model implementation including work intensification (De Angelis and Harvie, 2009). More recent data show that workload allocation models can reflect unequal power relations between practising academics and university management (Kenny, 2017) and do not necessarily shield academic staff from overload or overwork (Papadopoulos, 2017).

3 In the past, prior to the introduction of research assessment models, the minutia of academic workloads tended to apply to teaching only and was calculated on the basis of student load (typically full time equivalent (FTE) student enrolment). 
Some workload allocation models include targets for classification of academic staff as research active (or equivalent) and these tend to reflect, at least in part, output requirements for researchers under the relevant research assessment scheme (Burgess et al., 2003, p. 224; Watermeyer, 2016). This has contributed to the categorisation of academic workers in new ways-such as "research leader", "research active" or "teaching scholar" (amongst others). Wright et al. note that "[b]eing ... labelled "research inactive" (the equivalent of teaching scholar) can have extremely negative consequences for academics and their careers (2014, p. 14), including for academic identity and consciousness $\left(15^{-16)}\right.$. This is despite some efforts to improve the relative importance and status of university teaching and reflects research output as the primary determinant of the status of individual universities and individual academics within global higher education and disciplinary fields (Rowlands, 2017a).

\section{Illustrations of Research Output as a Potential Contributor to} Academic Workload Calculations

As a way of foregrounding subsequent theoretical analysis, we provide two short generic vignettes, one each from Australia and the UK. These serve to indicate some of the principles and potential impacts of academic workload allocation models on academics' research practices, noting that there is enormous variation within and between each nation state. While these vignettes are grounded in practices in a general sense, they are not indicative of a particular university or universities.

\subsection{Australian Exemplar}

Although workload models vary within and between institutions, in many Australian universities an hours-based system applies (Kenny and Fluck, 2017) within which "points" (as a proxy for workload hours) are allocated for designated research outputs previously produced, typically over a three-year rolling period. For example, one point may be allocated for each article published in an ERA recognised journal and five points may be allocated for a researchbased book or monograph published by a recognised academic publisher. Points are also allocated for competitive research grant income and higher degree by research completions, but for the purposes of this analysis the focus is on the publication output targets prescribed by the workload model.

Within our generic Australian workload model example, a research allocation for the following year is "earned" by meeting or exceeding specified targets for research output within the preceding three years according to an academic's 
relative level of appointment. Publication output requirements are rapidly increasing within many Australian universities. For example, within the disciplines of humanities, arts, social sciences and education in our Australian exemplar university, they increased by $40 \%$ between 2013 and 2015 and, more recently, a quality proxy hurdle was imposed in addition to the pre-existing quantitative indicator. Currently, to obtain 1.5 points for a published article, the journal in which it is published must meet certain impact factor thresholds otherwise only 1 point is awarded. For example, a level C academic (senior lecturer) must publish 5 papers over 3 years in Scimago quartile 1 or 2 journals, or 7 papers in other ERA recognised journals (or some combination of the two) to accrue the points necessary for a $40 \%$ research allocation and a designation of "research active". Publications that are not eligible for submission for ERA assessment are not awarded any points under this model. This Australian case presents two common but conflicting measures of successquantity and quality (as measured by proxy) - that are imposed simultaneously. Yet, as indicated above, it is quantity that dominates this relationship. In this model, being designated "not research active" or equivalent results in a substantially increased teaching allocation and a corresponding decrease in research time allowance. It also has significant implications for academic promotion prospects.

\subsection{UK Exemplar}

Academic workload models are also ubiquitous in UK universities and are similarly calculated by the hour. In our exemplar case institution, the standard distribution for an academic on a research and teaching contract is one third $(33 \%)$ of their total workload. In addition to requirements for grant income and $\mathrm{PhD}$ supervision, research and teaching academics are expected to produce four research outputs over the most recent seven-year period, the typical time between research assessments. That is, in our case institution, there is a quantity hurdle requirement but it is low, at less than one paper per year, and the same quantity standard applies to all academic levels. It is the quality requirement that increases across the different levels of academic appointment, from lecturers (at least two outputs should met the REF criteria of international excellence $\left(3^{*}\right)$ or better) to professors (at least 4 outputs should met the REF criteria of world leading $\left(4^{*}\right)$ ). Researchers who cannot demonstrate that they are on track to reach these targets are in danger of reassignment (managed through the annual performance review process) to teaching-only contracts, with a research allocation (rebadged as scholarship) of just $10 \%$. Although the specific arrangements may vary considerably from university to university, in the relationship between quality and quantity in the UK, it is quality that 
dominates. Moreover, unlike Australia, the impact of these publication output targets is not felt at the point of workload allocation but in terms of performance review and promotion application.

As previously noted, research output targets as a component of academic workload models in both Australia and the UK appear to be influenced, to varying extents, by their respective national research assessment schemes and thus work out differently in these different contexts. However, our interest is not in these models for their own sake. Instead, we focus on their potential effects on the research practices of academics themselves-on the practices of creating and disseminating new knowledge, specifically on the publication of research findings. Within this section we commence this analysis drawing further on Bourdieu's theory of practice and on the relationship between practice and habitus.

Earlier we observed that the habitus engenders practice within fields. Here, we acknowledge the considerable academic debate about the extent to which the below-the-level-of-consciousness characteristic of the habitus results in practice that is mechanistic or automatic. This debate is related to charges that the habitus is deterministic, leaving too little scope for self-determination or change (see for example Jenkins, 1982). Although Bourdieu vigorously disputed these accusations as a misreading (see Bourdieu and Wacquant, 1992), we accept Mead's argument that while Bourdieu's own characterisation of the habitus was at times not helpful in this regard, the habitus nonetheless leads to practice that is "irreducible to one's conscious intentions" (Mead, 2016: 58).

Although habitus can be at least partly read from practice (Bourdieu and Wacquant, 1992) the relationship is not simple and unidirectional. In Outline of a Theory of Practice, Bourdieu notes that the habitus is "determined by the past conditions which have produced the principle of their production, that is, by the actual outcome of identical or interchangeable past practices" (Bourdieu, 1977, pp. 72-73). This suggests that not only does an agent's habitus influence their practice, but that an agent's past practices, those things they have done in the past, are a factor in shaping and reshaping their own habitus (Rowlands and Gale, 2017). This would see an agent's own practices being a form of pedagogic work on themselves. Indeed, Swartz' examples of pedagogic work, which include "imitation, repetition, role-play, and game participation" (2002, p. 635), imply as much. These are not activities that are done to us by others but are instead activities in which agents engage themselves. That is, when an agent is 
engaged in playing a game, in the Bourdieuian sense of game as a metaphor for practice, their game playing becomes a form of pedagogic work that, in turn, contributes to a reshaping of their habitus. The emphasis on past practices is relevant here because the role of pedagogic work suggests that the habitus is more likely to reflect the past than the present (Bourdieu, 1990, p. 77). Thus, Bourdieu describes the relationship between habitus and practice as "the product of a dialectical relationship between a situation and a habitus ... [that] makes it possible to accomplish infinitely differentiated tasks, thanks to the analogical transfer of schemata acquired in prior practice" (Bourdieu, 1972, p. 261 as cited in Wacquant, 2016: 66). However, it is also the practices of the present that can potentially shape and reshape the habitus of the future (Rowlands and Gale, 2017).

The above discussion may seem unremarkable but its implications are relevant in the context of compliance with publication output targets associated with academic workload models. While the targets themselves are likely imposed by others, typically by management, the practices to comply (or not, as the case may be) are an agent's own. That is, individual academics have a degree of agency over how to respond to those targets and can adjust their practices accordingly. However, we draw on this theoretical analysis to speculate that not all options are equally available, or even knowable, to all academics.

Some academics might potentially marshal their already high levels of intellectual capital to produce high quality publications in sufficient numbers to meet the institutionally imposed output targets at the same time as establishing or retaining their position within their disciplinary field of research. The research practices of these academics can remain somewhat unchanged by the workload model. For them, it is more a case of continuing with what they were already doing at the same time as anticipating or responding to changes in the rules of the game or indeed advocating for changes to the rules to advantage their interests or indeed the interests of others. Academics thus categorised are often taken as models of practices and dispositions for other academics, and can become viewed as idealised standards of intellectual capital.

For academics with fewer reserves of intellectual capital the academic "game" might not be so straightforward. Some may choose to publish larger numbers of articles to meet targets for quantity but might not necessarily meet corresponding targets for quality, with potentially significant implications for workload allocations, for their standing within the disciplinary field and for future promotion prospects. This is a significant risk in Australia where despite evidence to the contrary (see Wilsdon et al., 2015) and therefore for reasons of economy and expediency, quality is defined solely by journal metrics. 
Moreover, the distinction of publishing in a high status journal is necessarily limited because such journals publish a finite number of papers per year.

Others may seek inclusion as an author on articles in which they have had little or no input, to raise their publication count and/or to increase their authorship of high quality articles. Some may opt out, or remain out of the research game altogether, showing their resistance by withdrawing from the field (Swartz, 2002) or experiencing what Grenfell has described as "inertia in the habitus" leading to an incapacity to make the most of the potential a newly transformed field may offer (2012, p. 35). In each of these instances, the research practice of the academic concerned has changed in response to the parameters of the research output calculation model.

It is here that the combined effects of publication output targets as part of academic workload allocation models and the implications for publication practices of national research assessment schemes become palpable. There are not only significant effects on workloads with proportionally higher or lower teaching allocations (and correspondingly greater or fewer research opportunities) but there are also implications for what it means to be a researcher - or not (Waitere et al., 2011; Chubb et al., 2017). Notwithstanding differences between the research assessment systems currently in place within the UK and Australia, the larger point is that regardless of these differences there are potentially similar and significant implications for changed practices by some academics (Oancea, 2014).

Earlier it was noted that habitus is not fixed following its initial formation. Instead it is continually reformed and reshaped through a process known as secondary pedagogic work, which takes place within educational organisations, the workplace and within other social institutions (Bourdieu and Passeron, 1977). Secondary pedagogic work is most likely to take place where there is a significant discrepancy between the habitus of the agent and the conditions of the field in which they are positioned (Mills and Gale, 2011; Bourdieu and Passeron, 1977).

Contemporary academic work requires practising academics to generate intellectual capital in the form of research outputs but also to wield considerable academic capital (in Bourdieu's terms) or management capital (Rowlands 2017) in order to respond to the requirements of performance monitoring and measurement associated with academic workload models and other similar mechanisms generated by the higher education field. Thus academics must not only juggle these two competing forms of capital but they must also straddle two different fields: the university or higher education field currently dominated by academic capital and where intellectual outputs are counted and ranked; and the global disciplinary field within which much intellectual 
capital is produced and to which many academic researchers seek to belong (Rowlands, 2017b). However, the logics of practice of these two fields can be quite different.

The requirements to comply with publication output targets associated with academic workload models potentially create a discrepancy between the academic habitus associated with research practice and the performative conditions of the university field that require measurement, monitoring and reporting. Agents can seek to reduce this discrepancy by complying with the targets to the extent that their capital allows. However, it is these same practices of complying that also constitute the secondary pedagogic work, therefore potentially reshaping that aspect of the academic habitus that comprises dispositions towards research. This is more likely to occur if the changed practices continue over an extended period of time, as seems probable given that national research assessment has existed in the UK for more than 30 years and is showing no signs of discontinuance there or in Australia, as elsewhere.

It seems logical then that one effect of efforts to comply with publication output targets might be a potential and long-term reshaping of dispositions towards research. Moreover, the below-the-level-of-consciousness aspect of the habitus means that this reshaping of dispositions towards research might potentially go unrecognised, at least in the everyday. This compliance-habitus effect has potential implications for the dispositions of researchers towards what research is done, how, by whom and where, and also for how researchers are disposed, or not, towards what research is perceived to be possible or desirable. It also has the potential for a reshaping of disciplinary fields arising from the changed research practices that might result. A re-orientation of the academic habitus within universities therefore has implications for both disciplinary fields of production and higher education fields of consumption with each governed by its own, distinct, logic of practice (Bourdieu, 1984).

\section{Conclusion}

Throughout we have sought not only to provide a brief explanation of Bourdieu's account of practice but have also argued that it could be possible, under certain circumstances, for one's own practices to constitute secondary pedagogic work on one's own habitus. We have made this argument in the context of the relationship between national research assessment exercises within the UK and Australia and publication output targets within academic workload models. Our argument has highlighted the potential for the practices that academics undertake in an attempt to comply with these targets, in whatever 
form they take, to serve as secondary pedagogic work and therefore contribute to a long-term reformulation of the academic or scientific habitus. In turn, this may potentially lead to a redefinition of what being a researcher and doing research actually mean.

Bourdieu's theories of practice, habitus, field and capital are useful for considering that the effects of complying with publication output targets may be far deeper than small changes to research practice that can simply be reversed whenever the targets might be removed. They also suggest that the implications for research practice of publication output targets associated with academic workload models are far more significant than decisions about whether to publish in books or journals and if so, which ones. Paradoxically for all academics, the time, effort and strategy necessary to "play the game" so as comply with the publication output targets associated with academic workload models not only require simultaneous juggling of academic and intellectual capital across fields, but also mean less time and energy for the research being counted.

All research and teaching academics are potentially impacted by publication output targets. However, drawing on this theoretical account we speculate that the research practices of those with existing high levels of both academic and intellectual capital might be reasonably expected to be least affected. Some of these may be established researchers who accrued their capital at a time and in places where performance pressures arising from governance regimes such as academic workload models, research assessment schemes and international rankings, did not exist or perhaps not to the same degree as they do now. Conversely, the analysis highlights the potential vulnerability of early career researchers, with comparatively low levels of academic and intellectual capital, to the effects of publication output targets and the pressures to produce publications assessable under national research assessment schemes, although we acknowledge that academics can be affected by these regimes regardless of their career stage. Thus, the potential for publication output targets to impact what research is done, how, by whom and where, has consequences that far exceed who publishes in which outlet. They also include considerations around what research is feasible within the time limits allowed by academic workload models and therefore how researchers are disposed towards research and how research itself is understood and practiced. Bourdieu's theory of practice has therefore contributed to our understanding that the effects of publication output targets upon research practice are likely to be much more profound than at first glance might be thought to be the case.

More generally we think there is a case for the use of Bourdieu's theory of practice in future empirical studies that consider the effects of research assessment frameworks and/or publication output targets on the actual research 
practices of academics, and on their dispositions toward that research. This is especially important in view of the compliance-habitus effect with its potential for changes to the academic habitus arising from practices to comply with research assessment frameworks and/or publication output targets and the implications of this for sustained academic engagement and voice in academic fields. At the same time the longer-term effects of governance mechanisms such as academic workload models on the conditions, practices and fields of research is yet to be fully explored (Glaser, 2016). The potential for intended and unintended consequences that threaten whole fields of disciplinary research or generations of researchers, or parts thereof, is something about which we should all be concerned.

\section{References}

Adams, J., and Gurney, K. (2014) Evidence for Excellence: has the signal overtaken the substance? An analysis of journal articles submitted to RAE 2008. London: Digital Science.

American Society for Cell Biology. (2012) San Francisco Declaration on Research Assessment. Available at: www.ascb.org/dora-old/files/SFDeclarationFINAL.pdf.

ARC. (2017) Excellence in Research for Australia. Available at: http://www.arc.gov.au/ excellence-research-australia.

ARC. (2018) Engagement and impact assessment. Available at: http://www.arc.gov.au/ engagement-and-impact-assessment.

Blackmore, J. (2010) Research assessment: a calculative technology governing quality, accountability and equity. In: J Blackmore, M Brennan and L Zipin (eds) Re-Positioning University Governance and Academic Work Rotterdam: Sense, 67-84.

Bourdieu, P. (1977) Outline of a theory of practice, Cambridge: Cambridge University Press.

Bourdieu, P. (1984) Distinction: A social critique of the judgement of taste, London: Routledge \& Keegan Paul.

Bourdieu, P. (1985) The social space and the genesis of groups. Theory and Society 14: 723-744.

Bourdieu, P. (1986) The forms of capital. In: J.G. Richardson (ed) Handbook of Theory and Research for the Sociology of Education. New York: Greenwood, 241-258.

Bourdieu, P. (1988) Homo Academicus, Cambridge: Polity.

Bourdieu, P. (1990) The Logic of Practice, Cambridge: Polity.

Bourdieu, P. (1996) The State Nobility: Elite schools in the field of power, Cambridge: Polity.

Bourdieu, P. (1998) Practical Reason: On the theory of action, Cambridge: Polity. 
Bourdieu, P. and Passeron, J.-C. (1977) Reproduction: In education, society and culture, London: Sage.

Bourdieu, P. and Wacquant, L.J.D. (1992) An Invitation to Reflexive Sociology, Cambridge: Polity Press in association with Blackwell Publishers.

Buchholz, L. (2016) What is a global field? Rethinking Bourdieu's field theory beyond the nation-state. The Sociological Review 64: 31-6o.

Burgess, T., Lewis, H. and Mobbs, T. (2003) Academic workload planning revisited. Higher Education 46: 215-233.

Burrows, R. (2012) Living with the h-index? Metric assemblages in the contemporary academy. The Sociological Review 6o: 355-371.

Butler, L. (2003) Modifying publication practices in response to funding formulas. Research Evaluation 12: 39-46.

Butler, L. (2010) Impacts of performance-based research funding systems: A review of the concerns and the evidence. Performance-based Funding for Public Research in Tertiary Education Institutions: Workshop Proceedings. OECD Publishing.

Chubb, J., Watermeyer, R. and Wakeling, P. (2017) Fear and loathing in the academy? The role of emotion in response to an impact agenda in the UK and Australia. Higher Education Research \& Development 36: 555-568.

De Angelis, M. and Harvie, D. (2009) 'Cognitive capitalism' and the rat-race: how capital measures immaterial labour in British universities. Historical Materialism: Research in Critical Marxist Theory 17: 3-30.

Fukuda-Parr, S., Yamin, A.E. and Greenstein, J. (2014) The power of numbers: A critical review of millennium development goal targets for human development and human rights. Journal of Human Development and Capabilities 15: 105-117.

Gale, T. and Mills, C. (2013) Creating spaces in higher education for marginalised Australians: principles for socially inclusive pedagogies. ELiSS 5: 7-19.

Geuna, A. and Piolatto, M. (2016) Research assessment in the uk and Italy: Costly and difficult but probably worth it (at least for a while), Research Policy, 45: 260-271. Research Policy 45: 260-271.

Glaser, J. (2016) German universities on their way to performance-based management of research portfolios. Sociologia Italiana 8: 151-176.

Grenfell, M. (2010) Being critical: the practical logic of Bourdieu's metanoia. Critical Studies in Education 51: 85-99.

Grenfell, M. (2012) Pierre Bourdieu: Key Concepts, Stocksfield, England.: Acumen.

Hammarfelt, B. and de Rijcke, S. (2015) Accountability in context: effects of research evaluation systems on publication practices, disciplinary norms, and individual working routines in the faculty of Arts at Uppsala University. Research Evaluation 24: $63-77$.

HEFCE. (2017a) How we fund research. Available at: http://www.hefce.ac.uk/rsrch/ funding/. 
HEFCE. (2017b) Initial decisions on the Research Excellence Framework 2021. Available at: http://www.hefce.ac.uk/pubs/rereports/year/2017/ref201701/.

Hicks, D. (2009) Evolving regimes of multi-university research evaluation. Higher Education 57: 394-404.

Hicks, D. (2012) Performance-based university research funding systems Research Policy 41: $251-261$.

Jenkins, R. (1982) Pierre Bourdieu and the reproduction of determinism. Sociology 16: $270-281$.

Johnston, J. and Reeves, A. (2018) An investigation into the role played by research assessment in the socio-geographic fragmentation of undergraduate economics education in the UK. Higher Education 76: 589-614.

Kenny, J. (2017) Re-empowering academics in a corporate culture: an exploration of workload and performativity in a university. Higher Education: 1-16.

Kenny, J. and Fluck, A. (2014) The effectiveness of academic workload models in an institution: a staff perspective. Journal of Higher Education Policy and Management 36: $585^{-602 .}$

Kenny, J. and Fluck, A. (2017) Towards a methodology to determine standard time allocations for academic work. Journal of Higher Education Policy and Management 39: $503-523$.

Khazragui, H. and Hudson, J. (2015) Measuring the benefits of university research: impact and the REF in the UK. Research Evaluation 24: 51-62.

Krucken, G. (2014) Higher education reforms and unintended consequences: a research agenda. Studies in Higher Education 38: 1439-1450.

Kwok, J.T. (2013) Impact of ERA research assessment on university behaviour and their staff. Melbourne, Australia: NTEU National Policy and Research Unit.

Lewis, J.M. (2014) Research productivity and research system attitudes. Public Money \& Management 34: 417-424.

Lucas, L. (2006) The research game in academic life, Maidenhead, England.: The Society for Research in Higher Education and Open University Press.

Marginson, S. (2006) Dynamics of national and global competition in higher education. Higher Education 52: 1-39.

Marginson, S. (2008) Global field and global imagining: Bourdieu and worldwide higher education. British Journal of Sociology of Education 29: 303-315.

Marques, M., Powell, J.J., Zapp, M., et al. (2017) How does research evaluation impact educational research? Exploring intended and unintended consequences of research assessment in the United Kingdom, 1986-2014. European Educational Research Journal: 1-23.

May, T. (2005) Transformations in academic production content, context and consequence. European Journal of Social Theory 8: 193-209.

McNay, I. (2015) Does research quality assessment increase output and give value for money? Public Money \& Management 35: 67-68. 
McNay, I. (2016) Imbalancing the academy: the impact of research quality assessment. Sociologia Italiana 8: 119-150.

Mead, G. (2016) Bourdieu and conscious deliberation: an anti-mechanistic solution. European Journal of Social Theory 19: 57-73.

Mills, C., and Gale, T. (2011). Re-asserting the place of context in explaining student (under) achievement. British Journal of Sociology of Education, 32(2), 239-256.

Oancea, A. (2014) Research assessment as governance technology in the United Kingdom: findings from a survey of RAE 2008 impacts. Zeitschrift für Erziehungswissenschaft 17: 83-110.

OECD. (2014) The state of higher education 2014. Paris: OECD Higher Education Programme (IM HE).

Papadopoulos, A. (2017) The mismeasure of academic labour. Higher Education Research \& Development 36: 511-525.

Rawolle, S. (2010) Practice chains of production and consumption: mediatized practices across social fields. Discourse: Studies in the Cultural Politics of Education 31: 121-135.

Rawolle, S. and Lingard, B. (2013) Bourdieu and Educational Research: thinking tools, relational thinking, beyond epistemological innocence. In: M Murphy (ed) Social theory and education research: understanding Foucault, Habermas, Bourdieu and Derrida. New York: Routledge, 117-137.

Reay, D. (2004a) Cultural capitalists and academic habitus: classed and gendered labour in UK higher education. Women's Studies International Forum 27: 31-39.

Reay, D. (2004b) 'It's all becoming a habitus': beyond the habitual use of habitus in educational research. British Journal of Sociology of Education 25: 431-444.

REF. (2014) REF 2014: Research Excellence Framework. Available at: http://www.ref .ac.uk/results/intro/.

REF. (2018a) REF 2021: Draft guidance on submissions (2018/or). Available at: http:// www.ref.ac.uk/publications/2018/draftguidanceonsubmissions201801.html.

REF. (2018b) REF 2021: Research Excellence Framework. Available at: http://www.ref .ac.uk/publications/2017/initialdecisionsontheresearchexcellenceframework2021. html.

Rowlands, J. (2013) Academic boards: less intellectual and more academic capital in higher education governance? Studies in Higher Education 38: 1274-1289.

Rowlands, J. (2017a) Academic Governance within Contemporary Universities: Perspectives from Anglophone nations, Singapore: Springer Nature.

Rowlands, J. (2017b) Deepening understandings of Bourdieu's academic and intellectual capital through a study of academic voice within academic governance. Studies in Higher Education.

Rowlands, J. and Gale, T. (2017) Shaping and being shaped: extending the relationship between habitus and practice. In: J Lynch, J Rowlands, T Gale, et al. (eds) Practice theory: diffractive readings in professional practice and education. Oxford: Routledge. 
Sato, I. and Endo, T. (2014) From the RAE-able to the REF-able? A note on formative reactivity in national research quality assessment. Research on Academic Degrees and University Evaluation 16: 85-104.

Schulze-Cleven, T. and Olson, J.R. (2017) Worlds of higher education transformed: toward varieties of academic capitalism. Higher Education 73: 813-831.

Shore, C. and Wright, S. (2015) Audit culture revisited: rankings, ratings, and the reassembling of society. Current Anthropology 56: 421-444.

Strathern, M. (2000) The tyranny of transparency. British Educational Research Journal 26: 309-321.

Swartz, D. (2002) The sociology of habit: the perspective of Pierre Bourdieu. The Occupational Therapy Journal of Research 22: 615-695.

Teichler, U., A. Arimoto and W.K. Cummings (2013) The Changing Academic Profession: major findings of a comparative survey, Dordrecht: Springer.

Vardi, I. (2009) The impacts of different types of workload allocation models on academic satisfaction and working life. Higher Education 57: 499-508.

Wacquant, L. (1989) Towards a reflexive sociology: a workshop with Pierre Bourdieu. Sociological Theory 7: 26-63.

Wacquant, L. (2011) Habitus as topic and tool: reflections on becoming a prize fighter. Qualitative Research in Psychology 8: 81-92.

Wacquant, L. (2016) A concise genealogy and anatomy of habitus. The Sociological Review 64: 64-72.

Waitere, H.J., Wright, J., Tremaine, M., et al. (2011) Choosing whether to resist or reinforce the new managerialism: the impact of performance-based research funding on academic identity. Higher Education Research \& Development 30: 205-217.

Warde, A. (2004) Practice and field: Revising Bourdieusian concepts, CRIC Discussion Paper No. 65. Manchester: University of Manchester.

Watermeyer, R. (2016) Impact in the RE F: issues and obstacles. Studies in Higher Education 41: 199-214.

Webb, J. (2012) The logic of practice? Art, the academy, and fish out of water. Text 14: $1-15$.

WEF. (2018) 4 ways universities are driving innovation. Available at: https://www.weforum.org/agenda/2018/o1/4-ways-universities-are-driving-innovation/.

Wilsdon, J., Allen, L., Belfiore, B., et al. (2015) The Metric Tide: Report of the Independent Review of the Role of Metrics in Research Assessment and Management. London: Higher Education Funding Council for England.

Wright, S. (2014) Knowledge that counts: Points systems and the governance of Danish universities. In: D Smith and A Griffith (eds) Under new public management: Institutional ethnographies of changing front-line work. Toronto: University of Toronto Press, 294-337. 
Wright, S., Curtis, B., Lucas, L., et al. (2014) Working paper 24: Research assessment systems and their impacts on academic work in New Zealand, the UK and Denmark. Working Papers on University Reform. Copenhagen: Department of Education, Aarhus University. 